\title{
Unhiding hidden urban madness: the asylum photographs of Claudio Edinger
}

Regent Professor of Spanish and women and gender studies at Arizona State University. He has nd he has hively on Argentine narrative and theater, Argentina, Brazil, and Uruguay. He has also served as an Inter-American Development Bank professo Fresno. Foster has held visiting appointments a of California-Los Angeles, University of CaliforniaRiverside, and Florida International University. He has conducted six seminars for teachers under the auspices of the National Endowment for the Humanities, the most recent in Sáo Paulo in summer 2013. hittp://orcid.org/0000-0002-8807-4957 E-mail: david.foster@asu.edu.

Recebido em: 4/5/2019. Aprovado em: 5/7/2019

Publicado em: 16/12/2019.

Endereço:

Ans Street, Tempe, Arizona, The United States of

America.

\section{Desvendando a loucura escondida da cidade: as fotografias do hospício de Claudio Edinger Des-cubrindo la locura mental urbana: la fotografia de asilo de Claudio Edinger}

David William Foster ${ }^{1}$

Arizona State University, School of International Letters and Cultures, Tempe, Arizona, The United States of America.

\section{ABSTRACT:}

Mental illness is an inescapable component of urban life. The Brazilain photographer Claudio Edinger devotes one of his major photobooks to a study of the São Paulo mental asylum, Jaqueri. This essay analyses the strategies of his analytical scrutiny of mental patients, with reference to associated ethical issues. Of particular interest is, necessarily, his emphasis on the body and its valid photographic representation.

Keywords: Edinger, Claudio; mental asylums in photography; Jaqueri mental hospital (São Paulo).

\section{RESUMEN:}

La enfermedad metanl es un componente inapelable de la vida urbana. El fotógrafo Claudio Edinger dedica uno de sus principales fotolibros al estudio del asilo mental de São Paulo, Jaqueri. Este ensayo analiza las estrategias de su escrutinio analítico de los pacientes mentales, con referencia a asuntos éticos que se relacionan al mismo. De particular interés, necesariamente, es el énfasis en el cuerpo y en su válida representación fotográfica. PALABRAS CLAVES: Edinger, Claudio; asilos mentales en la fotografía; Jaqueri, hospital mental (São Paulo).

\section{RESUMO:}

A enfermidade mental tornou-se um componente associado à vida urbana. 0 fotógrafo Claudio Edinger dedica atenção especial ao assunto em um dos seus principais fotolivros ao fotografar o asilo mental de São Paulo, Jaqueri. Nesse sentido, este ensaio analisa as estratégias utilizadas pelo fotógrafo brasileiro ao fotografar os pacientes da instituição, levando-se em consideração questões de ordem ética. Mais especificamente, analisaremos a sua ênfase ao corpo e a sua representação fotográfica.

Palavras-chave: Edinger, Claudio; asilos mentais na fotografia; Jaqueri, hospital mental (São Paulo). 
Madness has ceased to be-at the limits of the world, of man and death-an eschatological figure; the darkness has dispersed on which the eyes of madness were fixed and out of which the forms of the impossible were born. Oblivion falls upon the world navigated by the free slaves of the Ship of Fools. Madness will no longer proceed from a point within the world to a point beyond, on its absolute voyage; it will never again be that fugitive and absolute limit. Behold it moored now, made fast among things and men. Retained and maintained. No longer a ship but a hospital. (FOUCAULT, $p .35$ )

As for the viewer, this viewer, even many years after the picture was taken... well, one can gaze at these faces for a long time and not come to the end of the mystery, and the indecency of such co-spectatorship. (SONTAG, p.60)

A

we have learned from Michel Foucault and the genealogy of his cultural criticism, madness is essentially a social construct that functions in tandem with an ideologized norm of reason (or, a normal of ideologized reason). In such a dynamic, madness is that which does not conform to the parameters of reason, and it matters little whether what is called madness is a profile of behavior that is biologically motivated and cannot be fit into the matrix of reason, or whether the very parameters of reason induce madness, in the sense of a radical inability of individuals to adjust or conform to whatever parameters of reason to which they are called to adhere. Concomitantly, madness may be a static condition, or it may be an incremental process that may plateau into a static condition.

Thus, individuals who are identified as mad along the scale constructed within the parameters of reason will be identified as such and dealt with in accord with the institutional procedures that are operant in any given society that subscribes to a constructed standard of reason (which may or may not be all societies, to one degree or another). Modern so-called civilized Western societies and those who aspire to its principles have customarily created asylums for the housing of individuals so deemed, particularly where their madness may represent the potential of harm to themselves or to others. Much has been done in the past fifty years to redefine madness and to deinstitutionalize certain groups of individuals (albeit perhaps never in as rational a way as might be optimal). And much has also been done in terms of pharmacological treatment regimes where they are now recognized to be indicated.

Yet insane asylums remain very much intact, usually woefully understaffed, with the result of inadequate services and likely abusive conditions that are the consequence of inadequate resources and lax oversight. And as Foucault also pointed out, such asylums, as part of the façade of purportedly advanced civilization, are likely to be out of sight, which only contributes to their structural inadequacies. Hidden away-and it makes little difference if they are in marginal and rundown sectors of the modern city, like the Buenos Aires Instituto Borda or in villages of some distance from the metropolis, like Chile's Putaendo asylum - members of society reputed to be "sane" will have little or no contact with them beyond the possibility of visiting a confined friend or family member. And at that, those confined to mental asylums typically end up completely forgotten by the society of the sane and reasonable. ${ }^{2}$

Claudio Edinger's Madness (1997) is, in fact, based on his contact with the Hospital Psiquiátrico Juqueri, ${ }^{3}$ first in the form of his visits in 1984 to his grandmother, who was confined to the Juqueri, when he returned from living in New York; he began complementing these visits with photographs

Some major Latin Americna photography dealing with madness and insane asylums include Sara Facio and Alicia D'Amico, Humanario (1976; see Foster, "Sara Facio as Urban Photographer"); Eduardo Gil, (a) rgentina (2002; see Foster, “La Grande Patria in Lower Case”); Paz Errázuriz, with Diamela Eltit as lead author, El infarto del alma (1994; see Foster, "Love, Passion, Metropolitan Outcasts, and Solidarity at Putaendo"). There are undoubtedly others, but these projects are signed by some of the most important photographers of Latin America.

3 Edinger has been involved in a wide variety of photographic projects, and much of his work has been co-published in New York, as an documentary photographer (Edinger and Cavalcanti, in addition to Madness [published in Brazil as Loucura), as an art photographer (Edinger, São Paulo: minha estranha cidade linda), and as a New York photographer (EdinGer, Cityscapes). Edinger's Claudio Edinger is an overview of his work as a whole. One of Edinger's earliest photographic projects, from the years of his residence in New York City, during part of which time he lived in the legendary Chelsea Hotel, anticipates the focus on Madness. Chelsea Hotel (1983) is a dossier of photographs of Edinger's neighbors at the Chelsea, which was famous for the variety of artists, performers, and eccentrics who lived there as long-term residents. The vast majority of Edinger's subjects might be described as committed or aspirational grotesques, individuals whose eccentricity is exercised as a voluntary, deeply necessary, refutation of the bourgeois normal and the conventionally sane and reasonable. His photobook is distinguished by the inclusion of an essay on the Hotel by Pete Hamill, one of the New York City's great chroniclers. Edinger's gaze towards what can almost be called the grotesque is also on view in his New York photobook Cityscapes. 
of the institution taken during a two-week stay at the hospital, although the authorities subsequently refused to allow him further entrance into the institution (Edinger 5): "They feared I was documenting some exposé" (Erdinger 5), which of course, in a sense he was. ${ }^{4}$ Erdinger's visits to his grandmother and, therefore, his visits to the site of material for his photographic dossier bring with it the aforementioned issue of the location of such institutions. The Hospital Psiquiátrico Juqueri (it has gone historically by other names and is also identified in precontemporary Brazilian Portuguese orthography as Juqueri), is located several hours north of São Paulo in the city of Franco da Rocha; from the Google map it appears moreover to be located on the fringes of the city. This question raises, necessarily, what such an isolated institution may have to do with urban photography. It is, however, easy to surmise (even without having access to hospital records) that the occupants of Juqueri are not drawn from the far-flung countryside of the largest county in Latin America, but rather have been shunted off there, since the founding of the hospital in 1898, from the city of São Paulo itself-and in 1898, the effective distance between the metropolis and Franco da Rocha would have been many times greater.

It is a commonplace that requires scant confirmation that urban life will drive you mad, and although the daily madness induced by the struggle for survival in the postmodern megalopolis is unlikely to generate many candidates for institutionalization, the simple reversal of the proposition is eminently true: denizens of mental hospitals emerge from city life, where a particular conjunction of environmental factors, distributed throughout many levels of lived experience-family, neighborhood, social and political life, circumstances of employment, amorous/erotic fulfillment-achieve a confluence that produces whatever the parameters of reason find constitutes clinical madness. To this one might add, in terms of contemporary understandings of body chemistry, biological factors, although many of them are of direct and indirect consequence of the collective and personal environment. Edinger is unable to be concerned with the circumstances by which his subjects are confined to Juqueri, which would require, minimally, access to institutional records, family, and, indeed, the

The photographer does not address the matter of authorizations form the patients or their legal guardians for use of their likenesses in his book, although this matter appears not to have been of any concern to the hospital authorities, who originally allowed him photographic access to the grounds of the institution, only to withdraw it two weeks later (Persichetti, no page.). patients themselves. His photobook is satisfied, so to speak, with the simple fact that they are confined to the psychiatric institution therefore available, also so to speak, for the undertaking of his camera, initially unauthorized and eventually banned. What this means is that the photographer intervenes circumstantially in a virtually clandestine social order. Hence, the marginality of his unauthorized access parallels significantly the marginality of the institutional dynamics he examines, so much so that authorities are concerned with what he might reveal and for what purpose, and their proscription of his further intervention in the institution would seem to hardly derive from concern over the integrity of the patients, but rather the problematical legitimacy of the institution's very conduct. ${ }^{5}$ Even without knowing fully the circumstances by which Edinger was able to effect the thirty-nine images of his photodossier, the reader might well ask how and why did he have some authorized access to the institution that was very quickly withdrawn. In turn, the precarious nature of the bureaucratic grounding for his photographs leaves them as sociopolitically ungrounded as the inmates of Juquery are in their remove (apparently in most cases, permanently) from society. That is, both lack identatory standing, the latter because they have, to all intents and purposes, disappeared from the hegemonic rational (i.e., nonmad) society, the former because he has no bureaucratic ("rational") standing for his work. ${ }^{6}$ It is purely opportunistic, but the artist's well-seized opportunity does end up constituting a sociopolitically valid document of cultural production. Hence, the productive uses it serves for readers who, albeit in an uncomfortably voyeuristic fashion, are allowed access to a sociopolitical dimension they know exists, but are otherwise banned from having any reasonable (sic) access to.

5 The conduct of mental institutions came under close scrutiny as part of the historical revisionism of post-dictatorship culture. Not only did the military government subject mental institutions, along with all other government institutions, to an ideologically-driven neglect and/or deleterious intervention, but there is concrete evidence that the assessment of mental illness was a pretext for warehousing the socially inconvenient, as well as political detainees; additionally, mental institutions like the Juqueri made use of forms of torture. Moreover, the rigid and violence-prone authoritarianism of such establishments paralleled the practice of de-facto governance under the armed forces (see Sakaguchi and Marcolan). The noted journalist Renato Pompeu (1941-2014) was detained and tortured at the Juquery in the early 1970s, where he was also subsequently self-committed as a mental patient on several occasions, in part as a consequence of his torture there (Pompeu).

That is, toward such standing, one might think, for example, of a professional assignment from a licensed journalistic enterprise, a commission from the psychiatric hospital itself, participation in a constituted movement for social justice 
One of the dominant features of Edinger's photographs speaks directly to the ambiguous question of intrusive access, and this is the way in which the inmates of Juqueri stare fixedly and directly at the camera, as one can see in the privileged image of the dossier, the one that appears on the book jacket and is reproduced internally (it is the next-to-final one of the three dozen images included in Madness). It is not so much that the way in which the subjects of these photographs stare unabashedly at the camera, but the way in which that stare marks the psycho-emotional distance between them and the photographer. That is, the unabashed stare is part of a series of details that recur throughout the photographs that are indexes of the relationship between the inmates and their environment.7 They perceive at some level that they are in a setting that allows for behavior that would be considered antisocial outside that setting. Certainly, this is a clumsy way of saying that the setting in which they find themselves-a setting they are hardly likely to have chosen, and one that does nothing to legitimate them as acceptable social subjects-induces in the inmates a range of antisocial behaviors that the photographer inevitably captures, whether this is his goal or not.

Four major examples of such behavior are evident in Edinger's photographs. One is the unabashed, unguarded, and characteristically blank stare of the inmates, who seem to the see the camera as a strange but nonthreatening intrusion into their lived routine. The reader will assume that the blank stare is the consequence of the mental illness of the inmates, an index of their psycho-emotional disassociation from the so-called outside (that is, beyond them and their setting) world from which the camera appears and will, after its momentarily intrusion, disappear into. Only some of the inmates take note, through their fixed stare, of the appearance of the alien camera; the majority of them seem indifferent to it. The reader will want inevitably to contrast the indifference of the blank stare with the stare of surprise, hostility, amusement of photographic subjects caught unguarded on the street, such as one might find in the work of a legendary street photographer like Garry Winogrand. While the provoked reaction of Winogrand's random street subjects very much legitimates

The stare directed at the camera is a commonplace of spontaneous street photography, as say in the case of the paradigmatic work of Gary Winograd. The sort of hostile, bewildered, defiant stare captured in Winograd's images are remarkably similar to the stares of Edinger's institutionalized subjects. his photographic gaze-in the sense of confirming a circuit of human reaction between photographer and subject such that we know that "something" is taking place here that we might want to examine with concentrated attention-the blank gaze of the Juqueri inmates devalues the photographic gaze, to the extent that it is unable to engage the subject in any participation in the photographic experience. ${ }^{8}$ Conversely, the lack of psycho-emotional engagement is taken by the reader, in the form of an unquestioned convention, to be an index of the mental illness, the taken-for-granted madness, of the subjects of the photographs.

The second characteristic behavior the photographer captures, one commented on by the photographer in his introduction to Madness, is the nudity of so many of the patients, men and women (6). Edinger comments on how the Brazilian climate renders clothes superfluous (in many parts of Brazil, especially the center and north, street attire for many is a bare minimum). But this is not strictly true, for while the climate in Rio de Janeiro is fairly evenly warm night and day, throughout the year, São Paulo is far enough south for it to be quite chilly in the winter months $\left(40-50^{\circ} \mathrm{C}\right)$, and since a facility like Juqueri would lack central heating, one would, naked, have to be singularly impervious to low temperatures, which the reader might (again, as an unquestioned convention) assume mental inmates to be. And Edinger goes on to note that nakedness of both men and women in an environment like the Juqueri is because the taboo of bodily display between the sexes and even in a same-sex group is one of the many polite social conventions that disappear within the walls of a mental hospital. Of course, the result is that, as a consequence of the photographer's intervention-and one must always bear in mind that we are speaking here of Edinger's officially unsanctioned and therefore illegitimate intrusion into the world of the Juqueri-there is the matter of a compromised human dignity of the subjects.

There is no way to calculate or calibrate what might be the reader's reactions to these naked bodies in terms of a reader's understanding of them in terms of an erotic photography. Certainly, the majority of the inmates, through

8 This explains why, in the tradition of vernacular photography, the photographer will always urge subjects to "look at the camera and smile": if they don't smile, there is the risk that they will be understood as hostile to the putative friendly exchange that gives intimacy to the vernacular photographic experience. Concomitantly, when the subject does not smile, the reader may find it alternatively cute or strange and want to know why the photographic experience did not function as presumedly planned. 
the physical appearance of partial or complete nudity, including so-called full frontal nudity, show signs of abuse and neglect, along with deleterious nutrition and hygiene, which makes them hardly appealing in any comparison to what we think of as erotic photography. Yet, there is no accounting for the reader's potential erotic pulsion as a consequence of viewing these images, which is why prevailing social norms (whether putatively universal or, here, specifically Brazilian) might find these images a breach of the commitment to dignity for human subjects placed in conditions of powerlessness. In this regard, it is important to note that Edinger's commitment to exposing the horrors of insane asylums (as he implies in his preface) in his native country would not have been enough to overcome the simple fact of his unsanctioned access to the subjects that appear in his dossier. In the final analysis, then, there is no way to know or gauge the extent to which the nakedness of the subjects in Madness way carry an erotic charge for some readers. ${ }^{9}$

A quite different issue is the way in which such nakedness challenges the reader to dare to wonder about sexual contacts between the inmates, both of a homosexual as well as a heterosexual nature. This matter is directly related to the third deviation from social conventions beyond the walls of Juqueri. I am referring to the corporal intimacy. In many images, we see the bodies of the inmates existing in isolation from each other, and it is startling to see individuals (in various degrees of dress ${ }^{10}$ ) literally strewn about the floors, like unbloodied victims of a massacre. One could wax poetic in a grim way here and say such images do, in fact, record a massacre and its victims, the death in life that is manifested by patients of a mental asylum; the grimness is enhanced when we are not convinced that there is a consistent, rational, overseen medical practice to account for such patients to be there in the first place: the madness of the system and not of the inmates in any principled sense. But in other images, such as the privileged photograph that is being commented on here, we see not only the physical intimacy of naked male bodies, but an intimacy that extends to physical proximity and ensuing bodily contact, accidental and on purpose.

As one might also wonder, by contrast, about the deformed and mutilated subjects of the photography of Joel-Peter Witkin that appear in The Bone House (2000)

${ }_{10}$ And with varying degrees of body mass, from skeletal to pronouncedly obese, made all the more evident by their nakedness; there are very few bodies, feminine or masculine, in these three-dozen images that would match any prevailing standard of the ideally healthy or aesthetically attractive.
There are so many naked bodies jumbled together in this image that it is impossible to count them, and inevitably they are touching and intertwining is ways that would not be permissible in the "outside world," no matter how much more open Brazilian society is known to be to affectionate interbodily engagement. Again, it is impossible to discern how erotically provocative the consequences of physical proximity here would be for readers, but the question is very vividly pertinent as a correlative of the conjunction of living at Juqueri and the circumstances of the photographer's unlicensed intervention.

Finally, there is the matter of unconventional practices. Edinger's setting appears to be the shower, and aside from any practice of nakedness by individual patients, the men here are all naked because they are about to bathe. Public bathing has its own rituals and conventions, where, particularly among men, a certain amount of allegedly innocent sexual play may be involved, and perhaps it has its own less conventional inflections in the context of the mental asylum. This, even though Edinger's image raises questions as to what the sexual life, between and across the sexual divide, in an institution like Juqueri, with its decrepit facilities and presumedly understaffing, might be. (We see no staff in any of these images, but that is a coefficient of the semi clandestine manner in which Edinger executed his images, since a staff presence might question the legitimacy of his being there-which eventually did occur.) But Edinger would hardly have had the opportunity - and perhaps not the inclination — to photographs engaged in unquestionable sex, and the readers are left with the synecdoques of sex, like nakedness and physical intimacy, but never the so-called real thing.

What is more at issue is unconventional behavior of a nonsexual nature, such as details of dress: there is the image of a woman "dressed up" in a tattered dress and carrying a battered shoulder purse. In the image we are speaking of, it is a man who is covered in soap lather. One might at first say that he has just stepped out of the shower, covered as he happened to be, in soap lather, and, indeed, one might marvel how the institutional soap in this case is capable, contrary to expectations, of producing so much lather. But the lather here is not merely happenstance, and the man has applied it in such a way that it looks almost like ritual tribal markings. This is evident in the way in which it is basically confined in abundance to his torso, down to just beyond his genitals, while his arms and legs are uncovered, and it is also evident in the way in which it has been fashioned as a face mask, with skeletal openings, 
Day-of-the-Dead fashion, for the eyes and the mouth. The improvised mask gives the lather-framed eyes of the inmate even greater intensity as he stares directly at the camera, as though he had stepped out from the shower stall or chamber to stare at the intruder: one can speculate on whether there is any psycho-emotional content in this stare or if it is, after all and despite the uniqueness of the mask in the context of the other unlathered men, a blank stare.

Throughout Madness, there are examples of unconventional behavior, a great measure of which one would likely associate with a range of stereotypes associated with the comportment of asylum inmates. For example, there are numerous images of individuals in states of extreme abandon, such as sitting around and staring vacantly or grinning or grimacing in what appears to be a sustained way. There are also numerous images of bodies scattered on the ground as if, as stated above, the victims of a bloodless massacre. Some of these individuals are supposedly sleeping, while they have a wide-eyed look off as though gripped by an unbearable pain, emotional perhaps as much as physical. Because of the specific context of the Juqueri institution, these bodies are likely to be in varying states of undress or directly naked. Characteristically, with some notable exceptions (see below), there is no interaction between these individuals. My use of the adjective "abandoned" of course refers to the lack of any supervisory personnel (necessary in these cases for Edinger to have been able to take his photographs) and what that might imply in terms of regimes of control and treatment: the implication that there is little reinforces the assumption that the norm at Juqueri is the warehousing of the insane and little more. But the characterization of abandonment has another dimension to it, and that is the lack of communication between individuals. They are abandoned in a human community to incommunication, and there is, thus, the further assumption that institutional norms do nothing to further or stimulate communication between the patients. This abandonment is confirmed as much by the noncommunicational separation between individuals when seen as part of a group as it is by the many images of individuals who are off, so to speak, in a corner by themselves with no one around. The final image of a man in lying in a fetal position in an isolated corner confirms this general sense of the entire dossier.

In the case of an image of a female inmate lying seminude in front of a scarred low wall of the institution, one is immediately struck-beyond the potentially shocking immodesty of this and many of the photographs-by the look on the woman's face. Her eyes are apparently vacant and lack any object on which they might be focused. Additionally, they have moved so far to the right on her face that there is the presumption that she is either drugged or in some sort of catatonic state. Our gaze, thanks to the agency of the photographer, is intrusive, to the extent that it remains uncorresponded, quite the contrary from the image above in which the soapy mask of the foregrounded inmate only serves to intensify his deliberate act of staring at the camera and, therefore, at the readers of the image. As a consequence, as a correlative of her intense dissociative state, the woman can hardly be concerned about the way in which her breast seems more focused on the eye of the camera than her eyes do. And it is only because of the lay of her dress or wrap and the folds of her flesh that her genitalia are withheld from the view of the reader, something which is not true in other photographs. Indeed, in one image, the female pudenda is so manifestly evident that it would seem to be the whole point of the photograph, as in the case of several images that center on male genitalia.

This sort of intense intrusion of attention to the exposed bodies of the inmates is, certainly, a direct consequence of the occurrence of nudity at the Juqueri, but it is, from a more specifically ideological point of view, a consequence of the unrestrained access the photographer, if only momentarily, was able to achieve in his access to those inmates. Because that nudity is part of the "natural" or "customary" environment of the institution, the unauthorized intrusion of the artist's camera is all the more audacious in its documentary practice. And, concomitantly, the degree to which the reader might feel offended by the invasion of the inmates' privacy, particularly as regards the display of the body, speaks to the way in which the institutional norms are so alarmingly removed from the realm of what one might expect to be the humane treatment the inmates deserve and that, as Madness so manifestly wishes us to see, they are not receiving. Perhaps such nudity is neither scandalous or even problematical from the point of view of the caretakers, and perhaps it is something that might have evolved spontaneously among the patients because of circumstances of the climate without having been imposed by the administration. But from the point of view of us the readers from the outside, it is not surprising to find that those from the so-called rational world will see it as an institutional strategy for denying dignity to the patients, thereby dehumanizing them and making them easier to manage. Any other sort of unconventional behavior that 
is stereotypically associated with mental cases is overshadowed by both the nudity and the acquired ease of its display. Such a display puts them all that much farther removed from the "normal and "decent" world beyond the walls.

Significantly, an isolating wall is very much a part of this image. What we can see as part of the universe of the photograph beyond the wall is undoubtedly another installation of the Juqueri, rather than something like a house next door. ${ }^{11}$ This is why the wall is so low, since walls separating a mental hospital from the outside are customarily much higher, not so much, one might insist, to keep the patients in than to impede any curious or prying outside gaze. This, in turn, becomes another affirmation of the audaciousness of Edinger's penetration into the rigorously hidden world of the asylum. The building in the background may be part of the outside world, but it does highlight the separating wall and the woman's body reduced virtually to the detritus that it frames - at the moment for our own intrusive view only. One may well argue that so much photography, by definition, is intrusive, and especially documentary photography: the fixing of the fleeting moment; the lack of authorization that so frequently accompanies the capturing of the unexpected; the use of black and white, which has the effect of converting the quotidian world into artistic material characterized by subtle shadings of a monochrome. But there is a significant difference of intruding upon a social subject that can answer back and one that is unable to register the presence of the camera. Yet, as the first image discussed demonstrates, not all of the inhabitants of Juqueri are oblivious to the camera, and there is one image that is absolutely stunning in the power of the contestational gaze of the photographer on the part of the woman being photographed. Many of the features of her appearance are similar to those of the woman lying against the wall, especially as regards her seminudity. But the force of her almost growlingly responsive stare is jarring because it reminds us that not all of our intrusive gazes are free of charge.

The final image I wish to discuss returns us to the question of the erotic intimacy that may exist between inhabitants of the asylum and the degree to which it may be "enhanced" by the practice of nudity. As opposed to the images

An important aspect of Latin American traditional urban planning is evinced here: neighborhoods are highly mixed use, and both commercial and official installations (here, the Juqueri mental asylum) are not unlikely to be literally next door to private domestic residents. of naked men and women distributed in a nonproxemic way in the shared space they inhabit, or individuals who have, if even only momentarily, some degree of solitude that the photographer captures, in this image two naked men are holding hands. Although they don't really look into the camera (one may be doing so, but alternatively, one thinks his eyes may be almost fully closed), their faces evince what is, stereotypically, the foolish grin of the mentally ill.

The question that could immediately come to mind for the reader is what is the significance of the gesture of holding hands? It is a question that is complicated by the fact that both men are naked, which in most other contexts would be understood to signify an unmistakable erotic circumstance. In everyday life, in almost any place outside the Juqueri asylum, clothed/unclothed is a binary that has unmistakable semiotic consequences, to the extent that being unclothed is typically suggestive of erotic involvement, particularly where more than the isolated individual is involved. However, here, because of the virtual norm of nakedness in the Juqueri asylum, being unclothed in the company of others (as in the case of the cover image analyzed above) cannot be unquestionably read as erotically suggestive in and of itself. However, what does require interrogation, separate then from the state of unclothedness, is the separate sign of holding hands.

Nowhere else in Edinger's dossier is there any image of inmates engaged in suggestive physical proximity. They are naked together, but not interactively naked. Even the close proximity of the bodies in the shower that we see in the cover image does not bring with it any indication of anything other than the necessary nakedness of a shower setting. It is a shower setting that is characteristic of the overcrowding that one might expect in such an institutional setting, where there are always many times more inmates than the facilities were originally designed to handle, and thus bodies become on many occasions jammed together in a limited space. As a consequence, the fact that these two men are holding hands must signal a particular relationship between them in the context of the physical and mental alienation of the inmates as a whole. Brazilian society may be reputed to evince erotic behavior more openly than American society (which is, pace certain forms of cultural display, a highly problematic assertion). Yet, even if it may be true that there is a greater level of same-sex activity in Brazil than elsewhere, particularly in the United States, where Edinger's dossier was first published, Brazilian 
men do not hold hands in public, and this extends to men involved in what is a full-fledged homoerotic commitment. ${ }^{12}$

It would be naive to assume that forms of sexual interchange do not take place in mental institutions, whatever their degree of professional standing, and this would certainly include same-sex exchanges, even more so when the sexes are segregated, as seems to be the case in Edinger's photographs. Whether or not those exchanges involve any form of sexual exploitation or rape (whether between patients and their keepers or between patients of differing degrees of symbolic or real power) is another matter, beyond the photograph in question, but it would be equally naïve to assume such nonconsensual exchanges occur-indeed, one might likely assume that such nonconsensual exchanges are more highly likely than consensual exchanges mimicking the complexity of erotic relationships in the world external to the asylum. Of far greater interest, I would propose, is what one might understand by erotic relationships within the context of the asylum. The codes and rituals of sexual love in the so-called real world are so fraught with complex levels of misunderstanding, that it is difficult to imagine that they might in any way be reduplicated in any sort of setting of institutional confinement, where the spectrum of personal agency is radically foreshortened by both the control mechanisms of the institution and in the inherent physical and mental limitations of the inmates themselves. The latter are often used to explain or justify the strategies to impede sexual relations between inmates: if sexual conduct is an inherent human right, such rights are essentially rescinded by the structure of institutional settings, particularly and most typically penal and mental ones. However, this does not mean that sexual conduct does not take place, no matter how much it brings to the fore the matter of the nature and degree of consensuality.

What is perhaps of greater interest here, from the inherent human-interest point of view of the image, beyond institutional boundaries, is the question of the configurations of what may be considered sexual. From a semiotic point of view, holding hands is usually viewed as a preliminary synecdochal manifestation of sexual interaction. "This is how it begins" implies a chain of events that move,

12 The same thing may be true of lesbian lovers, but women are not involved here, so this matter need not be commented on further, except to say, obviously, that relations between women in Brazil, as elsewhere, have their own history separate from relations between men. Regard queer male sexuality in Brazil see Joa o Silvério Trevisão; Peter Fry examines the strategies of bourgeois decency in the face of Brazilian sexuality.

rather inexorably, from initial, putatively timid manifestations of attraction along a trajectory of practices that culminate, inevitably, in the "real" event: consummated genital engagement. The trajectory may be complicated in various ways and contain recursive details that make it a verisimilar figure of human behavior. But there is no question that when we see two individuals holding hands, it is reasonable that we speculate on what might be the subsequent fortune of their relationship. It is unlikely to speculate that holding hands will only culminate, as the total trajectory of their relationship, in passionate kissing; hope that it would go beyond that is a singular and principally viable, hopeful collaborative illusion. To feel otherwise, except for the blockage brought by ideological commitments such as specific religious beliefs about who gets to engage in sexual exnchages, would be reputed to be really rather mean spirited. How one might feel about that trajectory in the presence of hand-holding by mental patients may be another matter having to do with an acceptance of the rescindment of human rights in institutional settings.

But there is another way of viewing this image that has to do with alterations in the semiotic trajectory of erotic exchange between human beings, and this has to do with how the cirumstances of the alleged madness of mental inmates may alter that trajectory (the same could be said for reinterpreting the semantic trajectory of erotic involvement in the case, say, of the inmates of a penal institution, given the absolute guarantee of the universal material violence of such institutions). I would describe this alternative view of the erotic trajectory as metonymic rather than synecdochal, in the sense that, where the latter implies an aspirational chain of circumstances that culminate in supposedly fully erotic fulfillment, a metonymic configuration would imply that any isolated practice(s) in and of themselves will stand in for that fulfillment. What this means is that if the reader sees an image of two men holding hands (in a context in which their nakedness is superfluous to the semiotic meaning of holding hands), it does not necessarily mean that they are in any way in a condition to engage in a complete trajectory of amorous engagement. It is not that they can't or that they shouldn't (although instituionnal controls might work to impede their engagement). Rather, it is that, given all of the circumstances of their personal stories that have led to their confinement, they may not be in any physical or psychological condition to fully pursue the allegedly natural sexual trajectory that obtains for society as a whole. In this way, one evident act, that of holding hands, may well 
be the full extent of their shared emotional involvement-or, at least, we have no reason to assume that it might actually go anywhere else erotically. That is, then, holding hands is metonymic (in the sense that it is circumstantial) to an erotic relationship, without necessarily implying anything else-as much as the encouragingly collaborative reader might want to assume it does.

The complexity of this image in Madness is indicative of the many rather otherworldly issues Edinger's dossier of his possibly/probably not fully authorized photographs in the Juqueri mental ayslum serves to conjure up. In addition to reasonably implying the legitimacy of mental asylums and the circumstances of their warehousing of social subjects, the dossier raises important questions of the dignity and agency of these social subjects. Even when, from a metaphotographic point of view, it also raises questions as to how the photographic project-clandestine or otherwise-transgresses the dignity of the individuals being portrayed. Certainly this is a matter of some importance, especially when intruding on a situation of evident erotic content. But yet that situation is not, after all, fundamentally different from the overall access to the unguarded expressions of the inmates as a whole.

\section{References}

EDINGER, Claudio. Cityscapes. São Paulo: DBA, 2001.

EDINGER, Claudio. Claudio Edinger. São Paulo: DBA, 2006.

EDINGER, Claudio. Chelsea Hotel. São Paulo: Abbeville, 1983.

EDINGER, Claudio. Madness. São Paulo: DBA, 1997.

EDINGER, Claudio. São Paulo: minha estranha cidade linda. São Paulo: DBA, 2008.

EDINGER, Claudio; CAVALCANTI, Pedro. São Paulo: construção da cidade. São Paulo: Global,1999.

ELTIT, Diamela; ERRÁZURIZ, Paz. El infarto del alma. Santiago de Chile: Hueders, 2017.

FACIO, Sara; D’AMICO, Alicia. Humanario. Buenos Aires: La Azotea, 1976.
FOSTER, David William. La grande patria in lower case: Eduardo Gil's photography in (Argentina). In: FOSTER, David William. Urban photography in Argentina: nine artists of the post-dictatorship era. Jefferson: McFarland, 2007. p. 55-76.

FOSTER, David William. Love, passion, metropolitan outcasts, and solidarity at Putaendo: Diamela Eltit and Paz Errazuriz's el infarto del alma. In: FOSTER, David William (ed.). Latin American urban cultural production. Minneapolis: University of Minnesota, Hispanic Issues, 2008. chap. 8, p. 153-178.

FOSTER, David William. Sara Facio as urban photographer. In: FOSTER, David William. Buenos Aires: perspectives on the city and cultural production. Austin: U of Texas P, 1998. p. 170-194.

FOUCAULT, Michel. Madness and civilization: a history of insanity in the age of reason. Translation by Richard Howard. New York: Vintage Books, 1973.

FRY, Peter. Para inglês ver: identidade e política na cultura brasileira. Rio de Janeiro: Azahar, 1982. GIL, Eduardo. (A)rgentina. Buenos Aires: Ediciones Cuarto 14, 2002.

PERSICHETTI, Simonetta. Dançando com a luz. In: EDINGER, Claudio. Claudio Edinger. São Paulo: DBA, 2006.

POMPEU, Renato. Memórias da loucura. São Paulo: Alfa-Omega, 1983

SAKAGUCHI, Douglas Sherer; MARCOLAN, João Fernando. History unveiled in Juquery: intramural psychiatric care in the civic-military dictatorship. Acta Paulista de Enfermagem, São Paulo, v. 29, n. 4, p. 476-481, 2016. https://doi.org/10.1590/1982-0194201600065

SONTAG, Susan. Regarding the pain of others. New York: Farrar, Straus and Giroux, 2003 https://doi.org/10.3917/dio.201.0127

TREVISAN, João Silvério. Devassos no paraíso: a homossexualidade no Brasil, da colônia à atualidade. 5. ed. Rio de Janeiro: Record, 2002.

WINOGRAD, Gary. Garry Winogrand. New Haven: San Francisco Museum of Art, 2013.

WITKIN, Joel-Peter. The bone house. Santa Fe: Twin Palm, 2000. 